\title{
Multielemental inductively coupled plasma optical emission spectrometry analysis of nickeliferous minerals
}

\author{
Elizabet Abad-Peña ${ }^{\mathrm{a}, 1}$, María Teresa Larrea-Marín ${ }^{\mathrm{b}}$, Margarita Edelia Villanueva-Tagle ${ }^{\mathrm{c}}$, \\ Mario Simeón Pomares-Alfonso ${ }^{\mathrm{d}, *, 2}$ \\ ${ }^{a}$ Department of Chemistry, Faculty of Natural Sciences, University of Oriente, Avenida Patricio Lumumba s/n, CP 90500, Santiago de Cuba, Cuba \\ ${ }^{\mathrm{b}}$ National Center of Metallurgical Researches (CENIM, CSIC), Avenida Gregorio del Amo, 8, 28040 Madrid, Spain

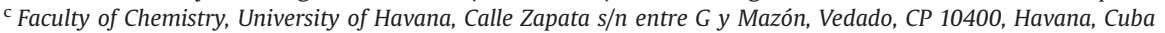 \\ ${ }^{\mathrm{d}}$ Institute of Materials Research and Engineering (IMRE), University of Havana, Calle Zapata s/n entre G y Mazón, Vedado, CP 10400, Havana, Cuba
}

\section{A R T I C L E I N F O}

\section{Article history:}

Received 18 October 2013

Received in revised form

29 January 2014

Accepted 31 January 2014

Available online 11 February 2014

Keywords:

Nickeliferous mineral

Matrix effect

ICP OES

Microwave-assisted digestion

Robust plasma

Matrix-matching calibration

\begin{abstract}
A B S T R A C T
An inductively coupled plasma optical emission spectrometry method for the quantitative simultaneous determination of $\mathrm{Al}, \mathrm{Ca}, \mathrm{Co}, \mathrm{Cu}, \mathrm{Cr}, \mathrm{Fe}, \mathrm{K}, \mathrm{Mg}, \mathrm{Mn}, \mathrm{Na}, \mathrm{Ni}, \mathrm{P}$ and $\mathrm{Zn}$ in Cuban laterite and serpentine minerals has been developed. Additionally, $\mathrm{V}$ and Ti can be quantitatively determined in laterite mineral; $\mathrm{Li}, \mathrm{Sr}$, and $\mathrm{Zr}$ can be detected in both mineral types and $\mathrm{Pb}$ can be detected just in laterite mineral. The microwave-assisted total acid digestion of samples was achieved with $\mathrm{HCl}+\mathrm{HNO}_{3}+\mathrm{HF}$ and $\mathrm{HNO}_{3}+\mathrm{H}-$ $\mathrm{ClO}_{4}+\mathrm{HF}$ acid mixtures for laterite and serpentine samples, respectively. In non-robust plasma operating conditions, the matrix effect characteristics of the laterite sample were dictated by the principal component $\mathrm{Fe}$; while the character of the $\mathrm{Mg}$ principal component matrix effect was some how modified by the concomitants $\mathrm{Fe}$ and $\mathrm{Ni}$ in serpentine sample. The selection of robust conditions decreased the matrix effect. Additionally, the simulation of the matrix samples by introducing the principal component $\mathrm{Fe}$ or $\mathrm{Mg}$, correspondingly, in calibration dissolutions was needed to overcome completely the matrix effect over the analysis accuracy. Precision of analysis was very near or lower than $10 \%$ for most elements, except $\mathrm{Sr}(15 \%)$ in $\mathrm{L}-1$; and $\mathrm{K}(15 \%)$ and $\mathrm{Li}(15 \%)$ in SNi sample. Accuracy of analysis was around or lowers than $10 \%$ for most elements, except K (15\%), Na (19\%), P (19\%) and V (19\%) in $\mathrm{L}-1$ sample; and Ca (14\%) and P (20\%) in SNi sample.
\end{abstract}

(c) 2014 Elsevier B.V. All rights reserved.

\section{Introduction}

The export of iron and cooper minerals from the west zone of Cuba began since 1902 by some foreigners companies such as the Bethlehem Steel Corporation. The deepest geological study on the presence of nickel in those ferruginous mineral deposits was carried out by researchers of the Padners Corporation (1939-1940). As result, the mineral body was characterized and the processing and extraction of nickel like matter has been prevailed since 1941 [1,2].

At present, the Cuban nickel deposits are recognized as one of the biggest in the world with, approximately, $37 \%$ of the nickel planet reserves. On the other hand, nickel industry represents one of the most important sectors of Cuban economy [3]. Seventy five thousand

\footnotetext{
* Corresponding author. Tel.: + 5378781136 .

E-mail addresses: elizabet@cnt.uo.edu.cu (E. Abad-Peña), m.larrea@cenim.csic.es (M.T. Larrea-Marín), villa@fq.uh.cu (M.E. Villanueva-Tagle), mpomares@imre.oc.uh.cu (M.S. Pomares-Alfonso).

${ }^{1}$ Present address: National Center of Metallurgical Researches (CENIM, CSIC), Avenida Gregorio del Amo, 8, 28040, Madrid, Spain.

2 Postal address: Calle Zapata s/n entre G y Mazón, Vedado, CP 10400, Habana, Cuba.
}

annual tons of nickel and cobalt mixture are currently produced from Cuban lateritic ores at three national hydrometallurgical plants. In connection with the prospecting and processing of this mineral, the determination of $\mathrm{Ni}, \mathrm{Co}$ and $\mathrm{Fe}$ has been carried out at the geological chemical laboratories of the Republic of Cuba for more than forty years.

As known, inductively coupled plasma optical emission spectroscopy (ICP OES) is worldwide employed in geological studies [4,5]. Also, ICP OES has been routinely used for determination of $\mathrm{Al}, \mathrm{Co}, \mathrm{Cr}, \mathrm{Fe}, \mathrm{Mg}, \mathrm{Mn}, \mathrm{Ni}$ and $\mathrm{Si}$ in Cuban lateritic minerals since 1996, according to developed appropriate laboratory guidelines $[6,7]$. However, this mineral contains other elements, which should be determined as well because of several reasons. Particularly, the monitoring of $\mathrm{Ca}, \mathrm{Cu}, \mathrm{K}, \mathrm{Na}$, and $\mathrm{Zn}$ concentration is important in order to prevent their possible negative influence on the extraction metallurgical process of Ni plus Co concentrated product $[8,9]$. Additionally, the extension of the characterization of lateritic minerals to others elements, such as $\mathrm{Cu}, \mathrm{P}$ and $\mathrm{V}$, can contribute to a better evaluation of the mineral body [10].

According to the currently employed ICP OES methodology in Cuban laboratories [6,7], the sample test portion is digested by a 
fusion technique with lithium metaborate. Then, it is dissolved in hydrochloric or nitric acid dissolution. The addition of a significant amount of reagent to sample (sample:lithium metaborate $=1: 10$ ) and the inherent laboriousness of the digestion procedure increases the risk of sample contamination and simultaneously reduces the net amount of sample to be analyzed. Consequently, an improvement of the limits of detections of determined analytes is not practically favoured.

In general, several alternative acid digestion procedures have been used instead of the fusion technique, prior to ICP OES elemental quantification of geological samples [11-16]. Among them, the microwave-assisted acid digestion has showed certain relevant characteristics such as, a shorter acid digestion time; better recovery of volatile elements and compounds, lower contamination levels, minimal volumes of reagents, more reproducible procedures and a better working environment. Generally, the proposed digestion methodologies involve two different acids combinations. In some reports [11-14], a mixture of nitric plus perchloric acids with a further addition of hydrofluoric acid, for the complete lixiviation of metals strongly linked to the crystalline lattice, has been employed. Also, a starting sample treatment with aqua regia $\left(\mathrm{HCl}: \mathrm{HNO}_{3}=3: 1\right)$, followed by the addition of hydrofluoric acid has been used $[14,15]$. The advantages or disadvantages of the both acid mixtures employed are not totally clear. In any case, the study and selection of an appropriate alternative acid digestion method of Cuban nickeliferous mineral for further ICP OES multielemental determination, including analytes at low concentration, is an important and necessary analytical task to be done.

On the other hand, an international recognized guideline standard method for the ICP OES analysis of nickeliferous minerals was not found in the reviewed literature. Moreover, ICP OES techniques have been relatively little reported [16-18] for the analysis of these minerals. Thus, the increment of the background intensity of the element spectral lines, caused by the high concentration of Fe, was compensated by matching Fe concentration in sample and calibration dissolutions [16]. In other work [17], ICP OES matrix effect was observed and further avoided by using the internal standard method. Finally, a simultaneous testing method for determination of few elements $\mathrm{Ni}, \mathrm{Co}, \mathrm{Fe}, \mathrm{Mg}$ in laterite type $\mathrm{Ni}$ deposit was reported [18].

In this context, the aim of the current work was to carry out an analytical study for the determination of $\mathrm{Al}, \mathrm{Ca}, \mathrm{Co}, \mathrm{Cu}, \mathrm{Cr}, \mathrm{Fe}, \mathrm{K}, \mathrm{Li}$, $\mathrm{Mg}, \mathrm{Mn}, \mathrm{Na}, \mathrm{Ni}, \mathrm{P}, \mathrm{Pb}, \mathrm{Sr}, \mathrm{Ti}, \mathrm{V}, \mathrm{Zn}$ and $\mathrm{Zr}$ in Cuban nickeliferous minerals by ICP OES. A special attention to the digestion of sample and matrix effect is given.

\section{Materials and methods}

\subsection{Nickeliferous mineral samples}

This work was focused on two types of Cuban nickeliferous minerals represented by the two reference materials (RMs), "Nickeliferous Laterite (L-1)" [19,20] and "Nickeliferous Serpentine (SNi)". Both RMs were manufactured at the Central Laboratory of Minerals José Isaac del Corral (LACEMI), as part of an international project with the participation of twenty eight laboratories from ten different countries. Eight diverse analytical techniques, Atomic Absorption Spectrometry, Inductively Coupled Plasma-Optical Emission Spectrometry, Colorimetry, Volumetry, Gravimetry, XRay Fluorescence, Potentiometry and DC Arc Atomic Emission Spectrography were employed in the certification process. The both types of selected minerals are the most important because they represent the $60 \%$ of the Cuban nickeliferous minerals with economical interest. On the other hand, the content of major elements of these two samples is extreme within the concentration interval of elements of the minerals that they represent. Thus, L-1 reference material is principally composed by $82 \%$ of goethite$\mathrm{FeO}(\mathrm{OH}), 6 \%$ of clay minerals, $5 \%$ of chromite- $\mathrm{FeCr}_{2} \mathrm{O}_{4}$ and $3 \%$ of serpentine- $\mathrm{Mg}_{3}\left[\mathrm{Si}_{2} \mathrm{O}_{5}\right](\mathrm{OH})_{4}$; while $\mathrm{SNi}$ reference material is composed by $88 \%$ of serpentine- $\mathrm{Mg}_{3}\left[\mathrm{Si}_{2} \mathrm{O}_{5}\right](\mathrm{OH})_{4}, 7.5 \%$ of goethite-FeO $(\mathrm{OH})$ and $2 \%$ of clay minerals. Concentrations of $\mathrm{Ca}, \mathrm{Cu}, \mathrm{K}, \mathrm{Na}$ and $\mathrm{P}$ in $\mathrm{SNi}$; and of $\mathrm{Ca}, \mathrm{K}, \mathrm{Na}, \mathrm{P}$ and $\mathrm{V}$ in $\mathrm{L}-1$ reference material, are given as approximated values, because of the high dispersion among concentrations reported by the participating laboratories. Nevertheless, they are still the best available reference concentrations that can be used for sake of statistical comparison with found concentrations.

\subsection{Instrumentation}

Microwave-assisted digestion of samples was carried out by using a Milestone ethos 1600 microwave lab station (Sorisole, Italy), which was operated at $2450 \mathrm{MHz}$ and output energy of $900 \mathrm{~W}$. Maximum temperature and pressure were of $300{ }^{\circ} \mathrm{C}$ and 100 bar, respectively. The microwave system is equipped with ten closed reaction vessels ( $100 \mathrm{~mL}$ capacity) made from polytetrafluoroethylene. The temperature inside the vessels was monitored by using a 300 Automatic Temperature Control Probe.

Measurements of the emission lines intensity were made in an axial view mode ICP OES SpectroArcos spectrometer (SPECTRO Analytical Instruments, Kleve, Germany) at operating parameters listed in Table 1.

\subsection{Reagents and calibration dissolutions}

65\% Suprapur-grade Nitric acid (Merck, Darmstadt, Germany), 25\% Suprapur-grade Hydrochloric acid (Panreac, Barcelona, Spain), 60\% Suprapur-grade Perchloric acid (Merck, Darmstadt, Germany) and 48\% Suprapur-grade Hydrofluoric acid (Panreac, Barcelona, Spain) were employed for sample digestion and/or dissolutions preparation; while the used deionised water of $18 \mathrm{M} \Omega \mathrm{cm}^{-1}$ of resistivity was obtained with a Mili- $Q$ system (Millipore, Bedford, MA, USA). Unielemental $10,000 \mathrm{mg} \mathrm{L}^{-1}$ CertiPURs standard dissolutions of $\mathrm{Al}, \mathrm{Ca}, \mathrm{Fe}, \mathrm{K}, \mathrm{Mg}, \mathrm{Mn} \mathrm{Na}, \mathrm{Ni}, \mathrm{P}, \mathrm{Ti}, \mathrm{Zr}$; and $1000 \mathrm{mg} \mathrm{L}^{-1}$ of $\mathrm{Co}, \mathrm{Cu}, \mathrm{Cr}, \mathrm{Sr}, \mathrm{Li}, \mathrm{Zn}, \mathrm{Pb}, \mathrm{V}$ (Merck, Darmstadt, Germany) were used for the preparation of calibration dissolutions and dissolutions used in the interference study.

For calibration purposes, two groups of multielemental dissolutions were prepared. The first group of five dissolutions contained six analytes, at the following concentration intervals: Al and Ni: 1-6 mg L ${ }^{-1}$; Cr: $1.4-4 \mathrm{mg} \mathrm{L}^{-1}$; Fe: $10-100 \mathrm{mg} \mathrm{L}^{-1}$; Mg: 4-40 $\mathrm{mg} \mathrm{L}^{-1}$; Mn: 0.6-3 $\mathrm{mg} \mathrm{L}^{-1}$. The second group included three calibration dissolution subgroups. The first one, did not contain

Table 1

Operating conditions for Spectro ARCOS ICP optical emission spectrometer.

\begin{tabular}{ll}
\hline Parameter & Value \\
\hline $\begin{array}{l}\text { Nebulizer model } \\
\text { Spray chamber type } \\
\text { Injector ceramic tube internal diameter }\end{array}$ & $\begin{array}{l}\text { Modified Lichte } \\
\text { Glass, cyclonic }\end{array}$ \\
Read time & $2.5 \mathrm{~mm}$ \\
Radiofrequency incident power: & $28 \mathrm{~s}$ \\
- Highest MgII/Mg I & $1400 \mathrm{~W}$ \\
- Lowest MgII/Mg I & $900 \mathrm{~W}$ \\
Plasma argon flow rate & $12 \mathrm{~L} \mathrm{~min}^{-1}$ \\
Nebulizer argon flow rate: & \\
- Highest MgII/Mg I & $0.8 \mathrm{~L} \mathrm{~min}^{-1}$ \\
- Lowest MgII/Mg I & $1.3 \mathrm{~L} \mathrm{~min}^{-1}$ \\
Auxiliary argon flow rate & $1 \mathrm{~L} \mathrm{~min}^{-1}$ \\
Sample uptake rate & $2 \mathrm{~mL} \mathrm{~min}^{-1}$ \\
\hline
\end{tabular}


matrix elements and the others two subgroups contained only $\mathrm{Mg}$ (1900 $\mathrm{mg} \mathrm{L}^{-1}$ ) and Fe (5000 $\mathrm{mg} \mathrm{L}^{-1}$ ), respectively; while concentration of nine analytes was the same in the three calibration dissolution subgroups. The concentration interval of analytes was: Ca: $1-20 \mathrm{mg} \mathrm{L}^{-1}$; Co: $1-8 \mathrm{mg} \mathrm{L}^{-1}$; Cu: $0.1-0.5 \mathrm{mg} \mathrm{L}^{-1}$; $\mathrm{K}: 0.5-$ $4 \mathrm{mg} \mathrm{L}^{-1}$; $\mathrm{Li}$ and $\mathrm{Sr}$ : $1-10 \mathrm{mg} \mathrm{L}^{-1}$; $\mathrm{Na}: 0.5-5 \mathrm{mg} \mathrm{L}^{-1} ; \mathrm{P}: 0.1-$ $1.5 \mathrm{mg} \mathrm{L}^{-1}$; Pb: $1-30 \mathrm{mg} \mathrm{L}^{-1}$; Ti: $1-15 \mathrm{mg} \mathrm{L}^{-1}$, V: $0.1-2.4 \mathrm{mg} \mathrm{L}^{-1}$; Zn: $1-20 \mathrm{mg} \mathrm{L}^{-1}$ and $\mathrm{Zr}: 1-30 \mathrm{mg} \mathrm{L}^{-1}$.

\section{Results and discussions}

\subsection{Spectral interferences and line selection}

A preliminary selection of the more sensitive lines of the nineteen elements $\mathrm{Al}, \mathrm{Ca}, \mathrm{Co}, \mathrm{Cu}, \mathrm{Cr}, \mathrm{Fe}, \mathrm{K}, \mathrm{Li}, \mathrm{Mg}, \mathrm{Mn}, \mathrm{Na}, \mathrm{Ni}, \mathrm{P}$, $\mathrm{Pb}, \mathrm{Sr}, \mathrm{Ti}, \mathrm{V}, \mathrm{Zn}$ and $\mathrm{Zr}$, initially considered in the present work, was made from the recommended database lines of the spectrometer software. The possible spectral interferences, produced by matrix elements $\mathrm{Al}, \mathrm{Cr}, \mathrm{Fe}, \mathrm{Mg}$, and $\mathrm{Ni}$ of both $\mathrm{SNi}$ and $\mathrm{L}-1$ samples, were investigated over spectral lines of the remaining fourteen elements $\mathrm{Ca}, \mathrm{Co}, \mathrm{Cu}, \mathrm{K}, \mathrm{Li}, \mathrm{Mn}, \mathrm{Na}, \mathrm{P}, \mathrm{Pb}, \mathrm{Sr}, \mathrm{Ti}, \mathrm{V}, \mathrm{Zn}$ and $\mathrm{Zr}$. With that purpose, the emission spectrum of each synthetic dissolution 1.5 and 1.9 (Table 2), that simulated the major elemental composition of L-1 and SNi samples, respectively, was visually compared to the spectrum of the corresponding matrix blank dissolution 2.5 and 2.9. Just the emission lines, free from spectral interferences (Table 3) were further considered.

\subsection{Study and selection of plasma operating conditions}

Generally, several parameters can be considered during the development of an ICP OES analytical methodology. However, in the present work the selection of the operating parameters is based on the study of the plasma robustness because of the strong and direct relationship between plasma robustness and the matrix effect; which is one of the most crucial limitations of the ICP OES analysis to be overcome [22]. Thus, selecting the robust plasma conditions should reduce the matrix effect and, consequently, the systematic error of analysis. In this context, it is useful to evaluate the behaviour of the plasma robustness with the variation of radiofrequency power and nebulizer argon flow rate; which are the principal parameters that exert a significant influence on the robustness.

As known [21], MgII 280.270 nm/MgI 285.213 nm (MgII/MgI) ratio is frequently used to evaluate the plasma robustness in ICP OES. In this work, MgII/MgI intensity ratio was measured during the nebulization of $10 \mathrm{mg} \mathrm{L}^{-1}$ magnesium dissolution for a total of sixty three radiofrequency power and nebulizer flow rate combinations. By keeping radiofrequency power constant at $0.9 \mathrm{~kW}, 1.0 \mathrm{~kW}, 1.1 \mathrm{~kW}, 1.2 \mathrm{~kW}$, $1.3 \mathrm{~kW}, 1.4 \mathrm{~kW}$ and $1.5 \mathrm{~kW}$; the nebulizer flow rate was varied at $0.5 \mathrm{~L} \mathrm{~min}^{-1}, \quad 0.6 \mathrm{~L} \mathrm{~min}^{-1}, \quad 0.7 \mathrm{~L} \mathrm{~min}^{-1}, \quad 0.7 \mathrm{~L} \mathrm{~min}^{-1}, \quad 0.9 \mathrm{~L} \mathrm{~min}^{-1}$, 1.0 $\mathrm{L} \mathrm{min}^{-1}, 1.1 \mathrm{~L} \mathrm{~min}^{-1}, 1.2 \mathrm{~L} \mathrm{~min}^{-1}$ and $1.3 \mathrm{~L} \mathrm{~min}^{-1}$. The obtained tendencies of $\mathrm{MgII} / \mathrm{MgI}$ as a function of $\mathrm{F}_{\mathrm{N}}$ and $\mathrm{P}$ were similar to those previously reported [23-28]. As a result, the plasma robust conditions selected were $P=1.4 \mathrm{~kW}$ and $F_{N}=0.8 \mathrm{~L} \mathrm{~min}^{-1}$; whereas the nonrobust conditions were $P=0.9 \mathrm{~kW}$ and $F_{N}=1.3 \mathrm{~L} \mathrm{~min}^{-1}$.

\subsection{Matrix effect study}

Dissolutions prepared for matrix effect study are shown in Table 2. The simulation of the elemental composition of sample dissolution was made by considering the total digestion of $0.250 \mathrm{~g}$ sample test portion in a final volume of $25 \mathrm{~mL}$, and the further $1: 100$ dilution of the dissolved sample in $4 \% \mathrm{v} / \mathrm{v} \mathrm{HNO}_{3}$ before his introduction in the spectrometer. Thus, dissolutions 1.5 and 1.9 simulated the matrix of dissolved L-1 and SNi samples, respectively. The rest of type 1 dissolutions simulated the individual major element concentration contained in each of the dissolutions 1.5 and 1.9. All type 1 dissolutions contained, also, the analytes to be studied at concentration of $10 \mathrm{mg} \mathrm{L}^{-1}$ (group I: $\mathrm{Cu}, \mathrm{Na}, \mathrm{K}, \mathrm{Li}$ and $\mathrm{Sr}$ ) or $30 \mathrm{mg} \mathrm{L}^{-1}$ (group II: Ca, Co, Mn, P, Pb, Ti, Zn, $\mathrm{Zr}$, and $\mathrm{V}$ ). Type 2 dissolutions (from 2.1 to 2.9 ) were the matrix blanks of type 1 dissolutions. The dissolution 3 contained only the

Table 2

Dissolutions prepared for the study of spectral interferences, matrix effect and limits of detection.

\begin{tabular}{|c|c|c|c|c|c|c|c|c|}
\hline \multirow[t]{3}{*}{ Dissolution } & \multicolumn{7}{|c|}{ Concentration $\left(\mathrm{mg} \mathrm{L}^{-1}\right)$} & \multirow[t]{3}{*}{$\mathrm{HNO}_{3}(\%, \mathrm{v} / \mathrm{v})$} \\
\hline & \multicolumn{5}{|c|}{ Matrix elements } & \multicolumn{2}{|l|}{ Analytes } & \\
\hline & $\mathrm{Al}$ & $\mathrm{Cr}$ & $\mathrm{Fe}$ & $\mathrm{Mg}$ & $\mathrm{Ni}$ & Group I ${ }^{a}$ & Group II ${ }^{\text {b }}$ & \\
\hline 1.1 & 190 & - & - & - & - & 10 & 30 & 4 \\
\hline 1.2 & - & 190 & - & - & - & 10 & 30 & 4 \\
\hline 1.3 & - & - & 5000 & - & - & 10 & 30 & 4 \\
\hline 1.4 & - & - & - & - & 110 & 10 & 30 & 4 \\
\hline 1.5 & 190 & 190 & 5000 & - & 110 & 10 & 30 & 4 \\
\hline 1.6 & - & - & 762 & - & - & 10 & 30 & 4 \\
\hline 1.7 & - & - & - & 1900 & - & 10 & 30 & 4 \\
\hline 1.8 & - & - & - & - & 190 & 10 & 30 & 4 \\
\hline 1.9 & - & - & 762 & 1900 & 190 & 10 & 30 & 4 \\
\hline 2.1 & 190 & - & - & - & - & - & - & 4 \\
\hline 2.2 & - & 190 & - & - & - & - & - & 4 \\
\hline 2.3 & - & - & 5000 & - & - & - & - & 4 \\
\hline 2.4 & - & - & - & - & 110 & - & - & 4 \\
\hline 2.5 & 190 & 190 & 5000 & - & 110 & - & - & 4 \\
\hline 2.6 & - & - & 762 & - & - & - & - & 4 \\
\hline 2.7 & - & - & - & 1900 & - & - & - & 4 \\
\hline 2.8 & - & - & - & - & 190 & & & 4 \\
\hline 2.9 & - & - & 762 & 1900 & 190 & - & - & 4 \\
\hline 3 & - & - & - & - & - & 10 & 30 & 4 \\
\hline 4 & - & - & - & - & - & - & - & 4 \\
\hline
\end{tabular}

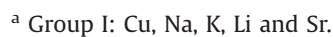

${ }^{\mathrm{b}}$ Group II: Ca, Co, Mn, P, Pb, Ti, Zn, Zr, and V. 
Table 3

Emission lines studied with the corresponding excitation energy for the atomic (I) and total excitation energy (excitation plus ionization energy) for the ionic (II) lines.

\begin{tabular}{|c|c|c|c|c|c|c|c|}
\hline Element & Energy $(\mathrm{eV})$ & Element & Energy $(\mathrm{eV})$ & Element & Energy (eV) & Element & Energy $(\mathrm{eV})$ \\
\hline $\mathrm{K}(\mathrm{I}) 766.491^{\mathrm{a}}$ & 1.62 & $\mathrm{Zn}(\mathrm{I}) 213.586^{\mathrm{d}}$ & 5.80 & $\mathrm{Zr}$ (II) 272.262 & 11.35 & $\operatorname{Co}\left(\right.$ II) $228.616^{a}$ & 13.70 \\
\hline $\mathrm{Li}(\mathrm{I}) 670.780$ & 1.85 & $\operatorname{Mg}(\mathrm{I}) 202.647$ & 6.12 & V(II) 292.402 & 11.38 & $\mathrm{Co}(\mathrm{II}) 230.786^{\mathrm{d}}$ & 13.75 \\
\hline $\mathrm{Na}(\mathrm{I}) 589.592^{\mathrm{a}}$ & 2.10 & $\mathrm{P}(\mathrm{I}) 178.287$ & 6.95 & $\mathrm{Zr}(\mathrm{II}) 257.139$ & 11.49 & $\mathrm{Ni}(\mathrm{II}) 231.604^{\mathrm{a}}$ & 14.03 \\
\hline $\mathrm{Na}(\mathrm{I}) 588.995$ & 2.10 & $\mathrm{P}(\mathrm{I}) 177.495^{\mathrm{a}}$ & 6.99 & $\mathrm{Mn}(\mathrm{II}) 260.569$ & 12.19 & $\mathrm{Ni}(\mathrm{II}) 221.648$ & 14.27 \\
\hline $\operatorname{Sr}(\mathrm{I}) 460.733$ & 2.69 & $\mathrm{Cu}(\mathrm{I}) 219.958$ & 7.02 & Mn(II) 259.373 & 12.21 & $\mathrm{~V}(\mathrm{II}) 311.071^{\mathrm{a}}$ & 14.49 \\
\hline $\mathrm{Ca}(\mathrm{I}) 422.673^{\mathrm{b}}$ & 2.93 & $\mathrm{Al}(\mathrm{I}) 176.641$ & 7.03 & $\mathrm{Mn}(\mathrm{II}) 257.611^{\mathrm{a}}$ & 12.24 & $\mathrm{Ca}(\mathrm{II}) 183.801^{\mathrm{b}}$ & 14.55 \\
\hline $\operatorname{Al}(\mathrm{I}) 396.152$ & 3.14 & $\mathrm{P}(\mathrm{I}) 214.914^{\mathrm{c}}$ & 7.18 & $\mathrm{Cr}(\mathrm{II}) 284.325$ & 12.63 & $\mathrm{~Pb}(\mathrm{II}) 172.680$ & 14.60 \\
\hline $\mathrm{Al}(\mathrm{I}) 394.401$ & 3.14 & $\mathrm{P}(\mathrm{I}) 213.618$ & 7.21 & Cr(II) 284.984 & 12.66 & $\mathrm{~Pb}(\mathrm{II}) 168.215$ & 14.78 \\
\hline $\mathrm{Ti}(\mathrm{I}) 334.187$ & 3.71 & $\mathrm{Zn}(\mathrm{I}) 334.502$ & 7.78 & Cr(II) 283.563 & 12.69 & $\mathrm{~Pb}(\mathrm{II}) 220.353$ & 14.79 \\
\hline $\mathrm{Na}(\mathrm{I}) 330.298$ & 3.75 & $\operatorname{Sr}(\mathrm{II}) 421.552$ & 8.63 & $\mathrm{Fe}(\mathrm{II}) 261.187$ & 12.69 & $\mathrm{Zn}(\mathrm{II}) 206.200^{\mathrm{a}}$ & 15.41 \\
\hline $\mathrm{Cu}(\mathrm{I}) 327.396^{\mathrm{a}}$ & 3.79 & $\mathrm{P}(\mathrm{I}) 169.403$ & 8.73 & $\operatorname{Mn}(\mathrm{II}) 294.921$ & 12.81 & $\mathrm{Zn}(\mathrm{II}) 202.613^{\mathrm{b}}$ & 15.51 \\
\hline $\mathrm{Cu}(\mathrm{I}) 324.754^{\mathrm{b}}$ & 3.82 & $\mathrm{P}(\mathrm{I}) 168.599$ & 8.76 & $\operatorname{Cr}(\mathrm{II}) 267.716^{\mathrm{a}}$ & 12.95 & $\mathrm{Fe}(\mathrm{II}) 244.451$ & 15.55 \\
\hline $\mathrm{Li}(\mathrm{I}) 323.261$ & 3.83 & $\mathrm{P}(\mathrm{I}) 138.147$ & 8.98 & $\mathrm{Fe}(\mathrm{II}) 238.204$ & 13.10 & $\mathrm{Cu}(\mathrm{II}) 224.700^{\mathrm{d}}$ & 15.96 \\
\hline $\operatorname{Mg}(\mathrm{I}) 285.213$ & 4.35 & $\mathrm{Zr}$ (II) 343.823 & 10.33 & $\mathrm{Fe}(\mathrm{II}) 239.562$ & 13.12 & $\mathrm{Fe}(\mathrm{II}) 259.941^{\mathrm{a}}$ & 16.09 \\
\hline $\mathrm{Pb}(\mathrm{I}) 283.305$ & 4.36 & $\mathrm{Zr}(\mathrm{II}) 339.198$ & 10.45 & $\mathrm{Ca}(\mathrm{II}) 315.887$ & 13.16 & $\mathrm{Cu}(\mathrm{II}) 219.226^{\mathrm{d}}$ & 16.21 \\
\hline $\mathrm{Pb}(\mathrm{I}) 405.778$ & 4.36 & $\operatorname{Ti}(\mathrm{II}) 336.121^{\mathrm{a}}$ & 10.54 & $\mathrm{Ca}(\mathrm{II}) 317.933^{\mathrm{a}}$ & 13.16 & $\operatorname{Mg}($ II $) 279.079^{a}$ & 16.51 \\
\hline $\mathrm{Li}(\mathrm{I}) 274.118$ & 4.52 & $\mathrm{Ti}(\mathrm{II}) 334.941$ & 10.58 & $\mathrm{Al}(\mathrm{II}) 167.078^{\mathrm{a}}$ & 13.41 & $\mathrm{~Pb}(\mathrm{II}) 167.153$ & 16.58 \\
\hline $\mathrm{Li}(\mathrm{I}) 460.289$ & 4.54 & $\mathrm{Ti}(\mathrm{II}) 323.452$ & 10.71 & $\mathrm{Co}(\mathrm{II}) 238.892^{\mathrm{d}}$ & 13.48 & & \\
\hline $\mathrm{Pb}(\mathrm{I}) 261.418$ & 5.71 & V(II) 292.464 & 11.34 & $\mathrm{Co}(\mathrm{II}) 237.862^{\mathrm{b}}$ & 13.51 & & \\
\hline
\end{tabular}

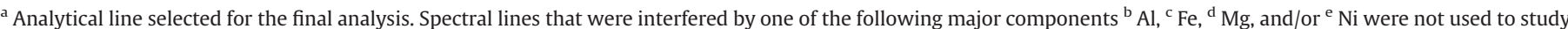
the matrix effect caused by that specific interfering major component.

analytes to be studied at the same concentration than type 1 dissolution. Finally, the dissolution 4 was the blank of dissolution 3. All dissolutions were prepared at $4 \%(\mathrm{v} / \mathrm{v}) \mathrm{HNO}_{3}$.

Matrix effect on free from spectral interferences analytical lines of analytes included in Table 3 was calculated, in percentage, according to Eq. (1)

$M E=\left[\left(\frac{I_{1}-I_{2}}{I_{3}-I_{4}}\right)-1\right] \times 100$

where, $I_{1}, I_{2}, I_{3}$ and $I_{4}$ were measured in the corresponding dissolution. Four replicates of each dissolution were measured at two different times during a working day; hence, the calculated ME was the mean of eight replicates.

In a first approach, the average of the absolute matrix effect over all studied analytical lines in Table 3 due to sample complex matrices and their single components $\mathrm{Al}, \mathrm{Cr}, \mathrm{Fe}, \mathrm{Mg}$ and $\mathrm{Ni}$, was evaluated in robust and non-robust plasma operating conditions by using synthetic dissolutions described in Table 2. In non-robust conditions, average matrix effect were significantly high, for both sample complex matrices $(\mathrm{Fe}+\mathrm{Mg}+\mathrm{Ni}$ and $\mathrm{Al}+\mathrm{Cr}+\mathrm{Fe} \mathrm{Ni}$ mixtures); and also for individual $\mathrm{Mg}\left(1900 \mathrm{mg} \mathrm{L}^{-1}\right)$, Fe $\left(762 \mathrm{mg} \mathrm{L}^{-1}\right)$ and $\mathrm{Fe}\left(5000 \mathrm{mg} \mathrm{L}^{-1}\right)$ matrices; while it was not significantly $(\sim 10 \%)$ in the presence of single $190 \mathrm{mg} \mathrm{L}^{-1} \mathrm{Al}, 190 \mathrm{mg} \mathrm{L}^{-1} \mathrm{Cr}$ and $110 \mathrm{mg} \mathrm{L}^{-1} \mathrm{Ni}$ matrices.

In robust conditions the average matrix effect was reduced. Obviously, from the practical point of view, if a better accuracy is desirable, then the use of non-robust condition has to be discarded. Nevertheless, a closer look to the effect in non-robust and the comparative study with the effect in robust conditions can facilitate the comprehension of the ICP OES matrix effect mechanisms; which are not totally understood from the theoretical point of view. In this context, the present study is useful and also novelty because the experimental evidences reported for matrix effect in ICP OES analysis of laterite and serpentine are very scarce in comparison with the effects reported for samples with others principal components such as, $\mathrm{Ca}, \mathrm{Mg}$ and easily ionized elements [24,29-31]. Consequently, a meticulous study of the dependence of the matrix effect with the total excitation energy of analytical lines (ME vs. TEE relationship) was carried out in non-robust (Fig. 1) and robust conditions (Fig. 2) for the individual Fe (762 $\mathrm{mg} \mathrm{L}^{-1}$ and $\left.5000 \mathrm{mg} \mathrm{L}^{-1}\right), \mathrm{Mg}\left(1900 \mathrm{mg} \mathrm{L}^{-1}\right)$ and for the both matrix elements mixtures.

In non-robust conditions (radiofrequency power $=0.9 \mathrm{~kW}$, nebulizer argon flow $=1.3 \mathrm{~L} \mathrm{~min}^{-1}$ ), intensity of most lines increased in the presence of laterite (Fig. 1a) and serpentine (Fig. 1b) simulated matrices, but the behaviour of the effect with the total energy excitation of lines depended of sample type. In the case of laterite, the effect was significant for most lines with energies in the intervals of approximately 1.62-4.0 eV and 10.0-16.0 eV (Fig. 1a); while no effect was observed for lines with energies around 7-9 eV. The high concentration of Fe decided, with no doubts, the conduct of matrix effect in laterite. Note that in the sole presence of Fe at two differente concentrations (Fig. 1c) a similar behaviour was observed. In both samples (Fig. 1a and c) the correlation between effect and energy lines was not significant. For Fe matrix (Fig. 1a), those results have not been reported in the reviewed literature [25,29,30,34]. In contrast with the results obtained for laterite matrix, the effect of serpentine simulated matrix (Fig. 1b) and individual Mg (Fig. 1d) was also significant for some lines with energy around $8 \mathrm{eV}$. However, the most interesting difference between serpentine and laterite matrix effect is the ME vs. TEE statistical significant dependence observed in serpentinite for energy lines lower than, approximately, $8 \mathrm{eV}$. In this case (Fig. 1b) a correlation coefficient $\left(R^{2}\right)$ of 0.63 was statistically significant for a $95 \%$ of probability with 12 degree of freedoms. Another difference respect to the ME vs. TEE behaviour of laterite and the principal role played by Fe in it is the surprising difference between the ME vs. TEE behaviour of serpentine and the principal component $\mathrm{Mg}$. It should be noted that no correlation between $\mathrm{ME}$ of $\mathrm{Mg}$ and TEE of lines with energies lower than $8 \mathrm{eV}$ was observed (Fig. 1d). Therefore, the appearance of some interaction effect among matrix elements in $\mathrm{Fe}+\mathrm{Mg}+\mathrm{Ni}$ serpentine sample is warranted. This interaction should be, principally, between $\mathrm{Fe}$ and $\mathrm{Mg}$, according to the relatively high concentrations of those elements, $762 \mathrm{mg} \mathrm{L}^{-1}$ and $1900 \mathrm{mg} \mathrm{L}^{-1}$ respectively, in comparison to the low $190 \mathrm{mg} \mathrm{L}^{-1}$ concentration of Ni. Obviously, the $\mathrm{Fe} /(\mathrm{Al}+\mathrm{Cr}+\mathrm{Fe}+\mathrm{Ni})=0.91$ concentration ratio in laterite, which is higher than the corresponding to serpentine $\mathrm{Mg} /(\mathrm{Fe}+\mathrm{Mg}+\mathrm{Ni})=$ 0.69 ratio, can be the responsible for the differences of the observed behaviour. A more detailed theoretical explanation is out the scope of the present work and requires additional experiments.

In robust conditions (radiofrequency power $=1.4 \mathrm{~kW}$, nebulizer flow $\operatorname{argon}=0.8 \mathrm{~L} \mathrm{~min}^{-1}$ ), beside the sensible reduction of the effect already mentioned before a drastic change in the effect type (enhancement or reduction of line intensity) and in the ME vs. TEE relationship was observed (Fig. 2). First, higher effects were observed for lines with energies in the extremes (around $2 \mathrm{eV}$ 

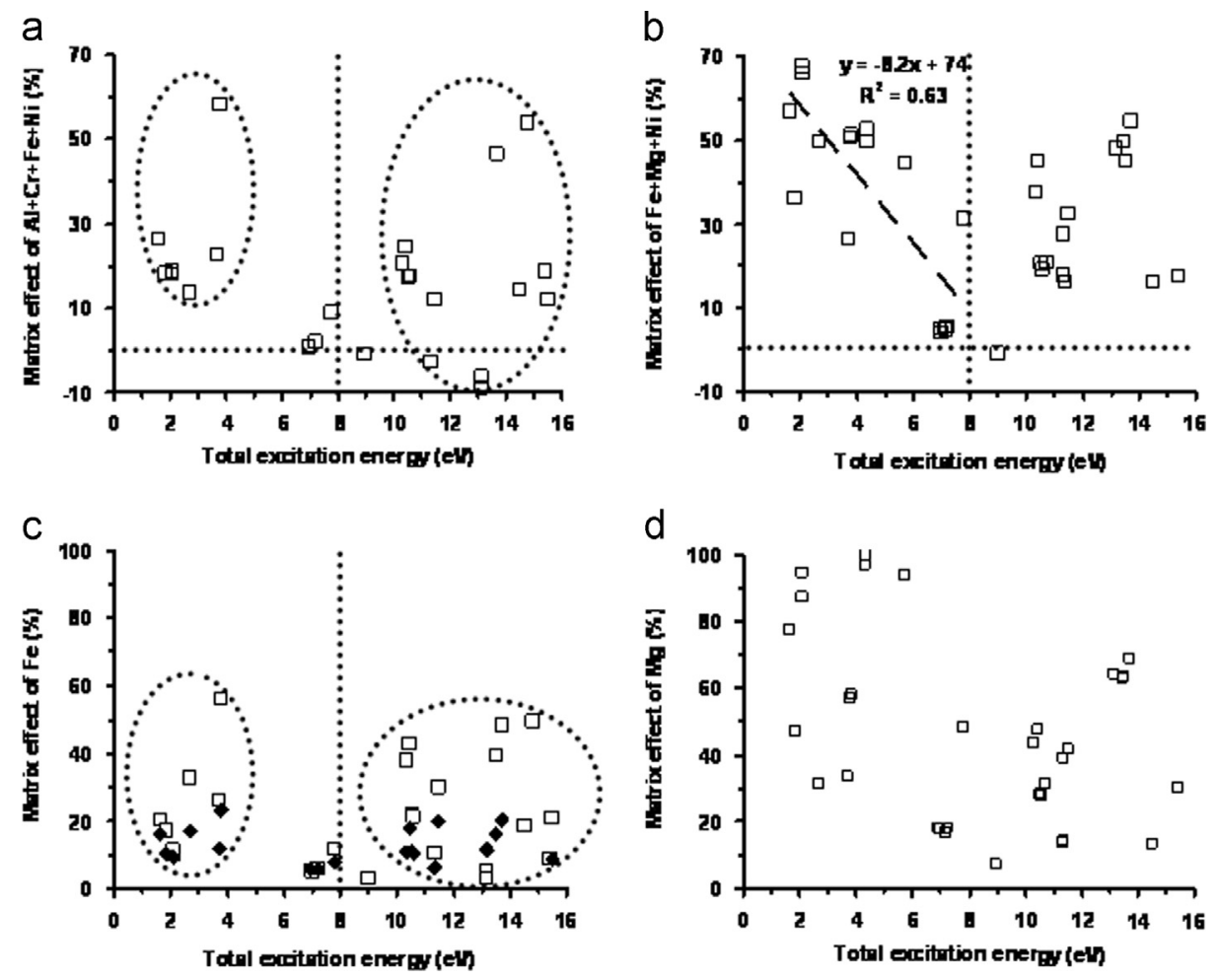

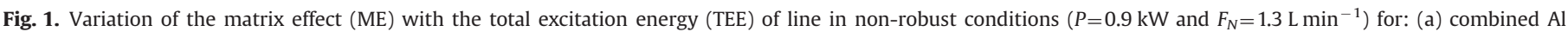

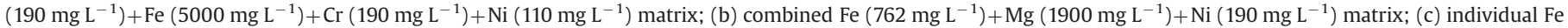
$\left(\square-5000 \mathrm{mg} \mathrm{L}^{-1},-762 \mathrm{mg} \mathrm{L}^{-1}\right)$ matrices; individual $\mathrm{Mg}\left(1900 \mathrm{mg} \mathrm{L}^{-1}\right)$ matrix.
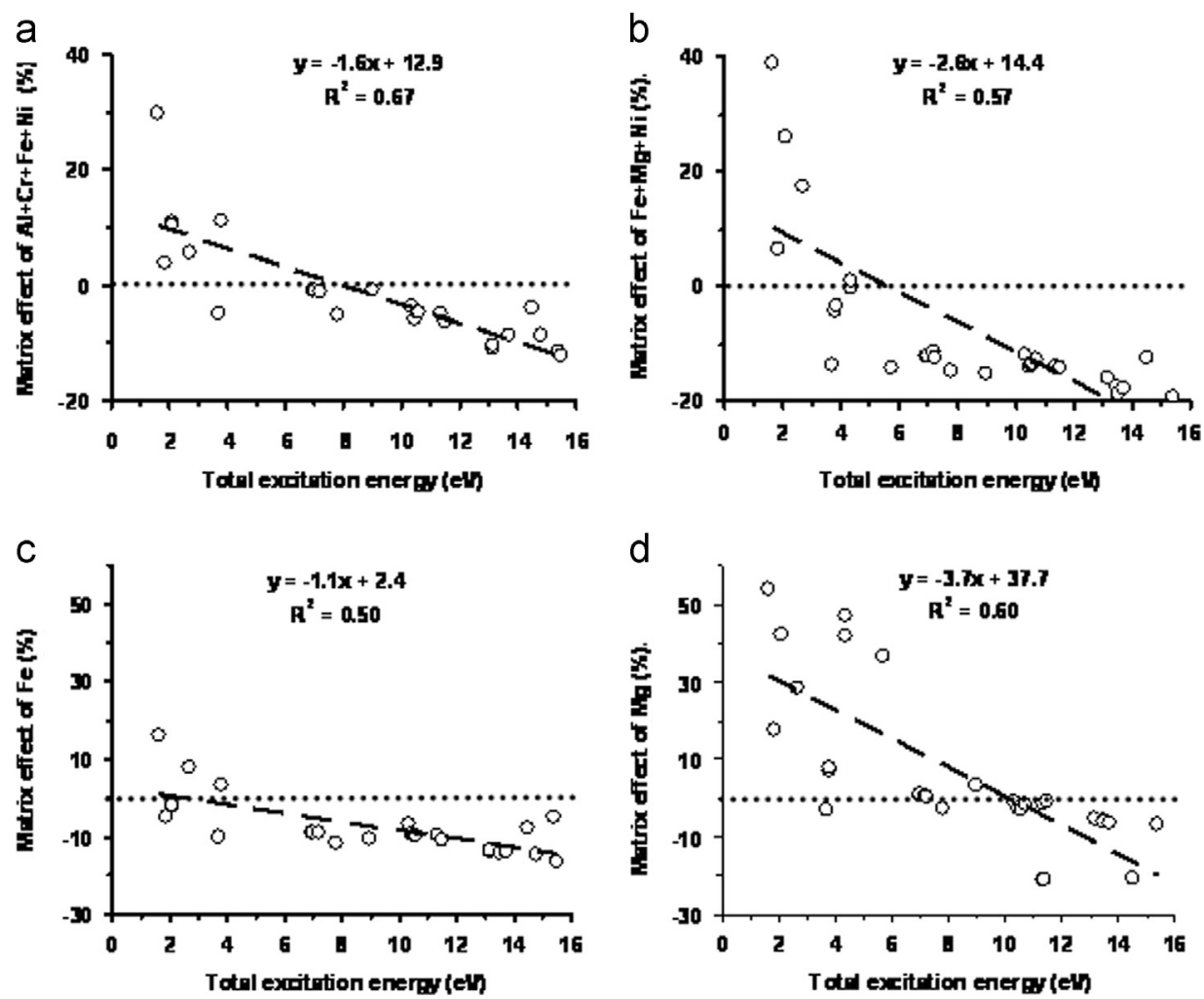

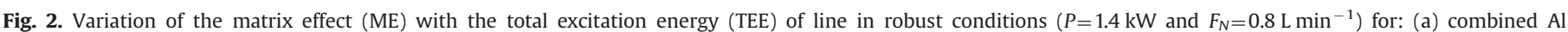

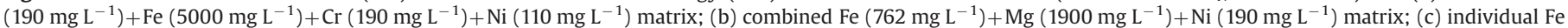
(5000 $\mathrm{mg} \mathrm{L}^{-1}$ ) matrix; (d) individual $\mathrm{Mg}\left(1900 \mathrm{mg} \mathrm{L}^{-1}\right)$ matrix.

and $16 \mathrm{eV}$ ) of the energy interval, but intensity of lines with higher energies decreased contrary to the increment occurred for the same lines in non-robust conditions. Second, matrix effect was directly proportional to the line energy for the combined $\mathrm{Al}+\mathrm{Cr}+\mathrm{Fe}+\mathrm{Ni}$ (Fig. 2a) and $\mathrm{Fe}+\mathrm{Mg}+\mathrm{Ni}$ (Fig. 2b); and for the individual Fe (Fig. 2C) and Mg (Fig. 2d) investigated matrices, with 
Table 4

Microwave-assisted heating programs.

\begin{tabular}{|c|c|c|c|c|c|c|c|c|c|c|c|c|c|}
\hline \multirow[t]{2}{*}{ Sample } & \multicolumn{2}{|c|}{ Program } & \multirow[t]{2}{*}{ Parameter } & \multicolumn{8}{|c|}{ Steps } & \multicolumn{2}{|c|}{ Total Time (min) } \\
\hline & & & & 1 & 2 & 3 & 4 & 5 & 6 & 7 & 8 & & \\
\hline \multirow[t]{4}{*}{ SNi } & \multirow{2}{*}{\multicolumn{2}{|c|}{1}} & Power (W) & 250 & 0 & 400 & 0 & 650 & 250 & 0 & - & & 30 \\
\hline & & & Time (min) & 5 & 5 & 5 & 5 & 3 & 2 & 5 & - & & \\
\hline & \multirow{2}{*}{\multicolumn{2}{|c|}{2}} & Power (W) & 250 & 0 & 400 & 0 & 600 & 0 & 250 & 0 & & 35 \\
\hline & & & Time (min) & 5 & 5 & 5 & 5 & 3 & 5 & 2 & 5 & & \\
\hline \multirow[t]{12}{*}{ L-1 } & \multirow{2}{*}{\multicolumn{2}{|c|}{3}} & Power (W) & 250 & 0 & 600 & 0 & 600 & 0 & - & - & & 27 \\
\hline & & & Time (min) & 10 & 2 & 3 & 4 & 3 & 5 & - & - & & \\
\hline & \multirow{2}{*}{\multicolumn{2}{|c|}{4}} & Power (W) & 250 & 0 & 600 & 0 & 600 & 0 & 600 & 0 & & 36 \\
\hline & & & Time (min) & 10 & 2 & 4 & 4 & 4 & 4 & 3 & 5 & & \\
\hline & \multirow[t]{4}{*}{5} & \multirow[t]{2}{*}{5.1} & Power (W) & 250 & 0 & 650 & 0 & - & - & - & - & \multirow[t]{2}{*}{21} & \multirow[t]{2}{*}{46} \\
\hline & & & Time (min) & 10 & 2 & 4 & 5 & - & - & - & - & & \\
\hline & & \multirow[t]{2}{*}{5.2} & Power (W) & 350 & 0 & 350 & 0 & - & - & - & - & \multirow[t]{2}{*}{25} & \\
\hline & & & Time (min) & 10 & 5 & 5 & 5 & - & - & - & - & & \\
\hline & \multirow[t]{4}{*}{6} & \multirow[t]{2}{*}{6.1} & Power (W) & 250 & 0 & 450 & 0 & 650 & 0 & - & - & \multirow[t]{2}{*}{37} & \multirow[t]{2}{*}{49} \\
\hline & & & Time (min) & 10 & 2 & 10 & 5 & 5 & 5 & - & - & & \\
\hline & & \multirow[t]{2}{*}{6.2} & Power (W) & 250 & 0 & - & - & - & - & - & - & \multirow[t]{2}{*}{12} & \\
\hline & & & Time (min) & 10 & 2 & - & - & - & - & - & - & & \\
\hline
\end{tabular}

Table 5

Digestion procedures investigated.

\begin{tabular}{|c|c|c|c|c|c|c|c|c|}
\hline \multirow[t]{2}{*}{ Sample } & \multirow[t]{2}{*}{ Digestion procedure } & \multirow[t]{2}{*}{ Mixture } & \multicolumn{4}{|c|}{ Acid volume (mL) } & \multirow[t]{2}{*}{ Total volume (mL) } & \multirow{2}{*}{$\begin{array}{l}\text { Microwave } \\
\text { heating program }\end{array}$} \\
\hline & & & $\mathrm{HNO}_{3}$ & $\mathrm{HClO}_{4}$ & $\mathrm{HF}$ & Aqua Regia & & \\
\hline \multirow[t]{3}{*}{$\mathrm{SNi}$} & D-1 & 1 & $5^{\mathrm{a}}$ & 2 & 1 & - & 8 & 1 and 2 \\
\hline & D-2 & 2 & $5^{\mathrm{b}}$ & 2 & 1 & - & 8 & 1 and 2 \\
\hline & D-3 & 3 & $2^{c}$ & 2 & 1 & - & 5 & 1 \\
\hline \multirow[t]{4}{*}{ L-1 } & D-4 & 4 & - & - & 3 & 3 & 6 & 3 \\
\hline & D-5 & 5 & - & - & 3 & 3.5 & 6.5 & 4 \\
\hline & D-6 & 6 & - & - & 3 & 4 & 7 & 5 \\
\hline & D-7 & 7 & - & - & 3 & 4.5 & 7.5 & 6 \\
\hline
\end{tabular}

a $5 \mathrm{~mL}$ of $\mathrm{HNO}_{3}: \mathrm{H}_{2} \mathrm{O}(1: 1)$.

b $5 \mathrm{~mL}$ of $\mathrm{HNO}_{3}: \mathrm{H}_{2} \mathrm{O}(2: 1)$.

c $2 \mathrm{~mL}$ of concentrated $65 \% \mathrm{HNO}_{3}$.

statistically significant correlation coefficients of $0.67,0.57,0.50$ and 0.60 , respectively. Precisely, the found correlation between matrix effect and total excitation energy of lines, allow assuring that the observed effect is predominantly related to the plasma excitation mechanisms of lines and not to others possible matrix effects generated during the introduction and transportation processes of sample into the plasma. The observed correlations in laterite and serpentine at robust conditions were similar to that reported for single $\mathrm{Al}, \mathrm{Ca}$ and $\mathrm{Mg}$ matrices [32]; and for a complex, $\mathrm{Pb}+\mathrm{Zr}+\mathrm{Ti}+\mathrm{Sr}$ matrix [33]. Again, this $\mathrm{ME}$ vs. TEE behaviour in robust condition seems to be no dependent of major element type.

Once the preliminary selection of the robust operating plasma parameters was done, a sample digestion procedure will be implemented.

\subsection{Microwave-assisted acid digestion of samples}

Six microwave-assisted heating programs, two for SNi; and four for L-1 were designed (Table 4). In programs 5 and 6, the samples were consecutively treated twice by using 5.1 and 5.2 ; and 6.1 and 6.2 subprograms, respectively.

According to the mineralogical composition of samples and the reviewed literature [11-15], the $\mathrm{HNO}_{3}+\mathrm{HClO}_{4}+\mathrm{HF}$ and aqua regia $+\mathrm{HF}$ acid combinations were studied for SNi and L-1 digestion, respectively. For SNi sample, $\mathrm{HNO}_{3}$ concentration was varied from $32.5 \%$ (mixture 1 ) up to $65 \%$ (mixture 3); while $\mathrm{HClO}_{4}$ and $\mathrm{HF}$ acid volumes were constant (Table 5). For L-1 sample, aqua regia varied from $3 \mathrm{~mL}$ to $4.5 \mathrm{~mL}$; while HF was kept constant. The used volumes of $\mathrm{HF}$ for each sample were selected in a previous experiment by evaluating, visually, the presence or absence of a precipitate; while, the others reagents were kept constant. Thus, a total of seven digestion options, three (D-1-D-3) for SNi; and four, (D-4-D-7) for L-1 were studied (Table 5). In D-1 and D-2 SNi procedures two consecutive heating programs were applied. Heating program 1 was run after addition of nitric acid to sample. After sample reached room temperature, similar amounts of HF $(1 \mathrm{~mL})$ and $\mathrm{HClO}_{4}(2 \mathrm{~mL})$ were successively added and then, the heating program 2 was run. In the D-3 procedure, $\mathrm{HNO}_{3}, \mathrm{HClO}_{4}$ and HF were successively added to sample. Then, the program 1 was run. For L- 1 sample, the aqua regia $+\mathrm{HF}$ acid mixture was added to $250 \mathrm{mg}$ of sample and, immediately, the corresponding program, was run. The total elimination of the HF acid residue from the sample dissolution was guaranteed by adding and heating, repeatedly, $0.5 \mathrm{~mL}$ of $\mathrm{HClO}_{4}$ until white vapours disappeared. Finally, dissolved samples were raised up to $25 \mathrm{~mL}$ with $4 \%$ (v/v) $\mathrm{HNO}_{3}$ dissolution. Five replicates of sample portions were digested in parallel and each replicate was measured six times at routine plasma conditions radiofrequency power $=1.4 \mathrm{~kW}$ and nebulizer flow gas $=1.0 \mathrm{~L} \mathrm{~min}^{-1}$. Others parameters were listed in Table 1 . The procedures were evaluated by comparing the found concentration in sample dissolution with the concentration of matrix elements reported in the certificate.

As can be seen in Table 6, the total content of $\mathrm{Al}, \mathrm{Cr}, \mathrm{Fe}, \mathrm{Mg}$ and $\mathrm{Ni}$ was totally transferred into dissolution, within the experimental error, when samples were digested by using the D-3 procedure. Thus, the increment of $\mathrm{HNO}_{3}$ concentration favoured, particularly, 
the total dissolution of Ni. Concerning L-1 sample, the content of $\mathrm{Al}, \mathrm{Fe}, \mathrm{Mg}$ and $\mathrm{Ni}$ was quantitatively recovered just by the procedure D-7; while $\mathrm{Cr}$ found concentration was lower than reference one.

According to the obtained results, D-3 and D-7 procedures were selected, in a first approach, for SNi and L-1 samples digestion, respectively.

\subsection{Influence of plasma robustness on precision of analysis}

The relationship between plasma robustness and matrix effect, and indirectly with the accuracy of analysis is well documented in the literature; however, experimental evidences of the influence of the robust conditions on the precision of the analysis are scarce $[24,29,34]$; and no references of such reports were found for nickeliferous minerals ICP OES analysis [5,16-18]. In this work, the influence of plasma robustness on precision of determination of $\mathrm{Al}, \mathrm{Cr}, \mathrm{Fe}, \mathrm{Mg}, \mathrm{Mn}$ and $\mathrm{Ni}$ was evaluated in non-robust and robust operating plasma conditions for $\mathrm{SNi}$ and L-1 samples. Precision was estimated as the relative standard deviation (RSD) of concentration for six replicates. In sample L-1, precision was more sensitive to plasma robustness than that in sample SNi.
Reduction of RSD in robust conditions was notable for mostly elements in L-1 sample; while precision was improved just for $\mathrm{Cr}$ and $\mathrm{Mn}$ in SNi sample. For all elements in both samples precision was lower than $5 \%$ in the robust conditions. The improvement of precision also justifies the selection of robust conditions.

\subsection{No matrix-matching and matrix-matching calibration curves.}

The use of the same no matrix-matching calibration curves (without matrix) for the analysis of $\mathrm{Ca}, \mathrm{Co}, \mathrm{Cu}, \mathrm{K}, \mathrm{Li}, \mathrm{Na}, \mathrm{P}, \mathrm{Pb}, \mathrm{Sr}, \mathrm{Ti}$, $\mathrm{V}, \mathrm{Zn}$ and $\mathrm{Zr}$ in both SNi and L-1 samples would be very attractive. However, the presence of a remaining matrix effect in robust conditions, previously discussed in Section 3.3, could affect the accuracy. Therefore, analysis was made by using the both types of calibration curves for comparison purposes (Table 7).

In a first approach, let to evaluate the determination of $\mathrm{Ca}, \mathrm{Co}$, $\mathrm{Cu}, \mathrm{K}, \mathrm{Li}, \mathrm{Na}, \mathrm{P}, \mathrm{Pb}, \mathrm{Sr}, \mathrm{Ti}, \mathrm{V}, \mathrm{Zn}$ and $\mathrm{Zr}$ in both $\mathrm{SNi}$ and $\mathrm{L}-1$ samples by using no matrix-matching calibration curves. In SNi sample analysis, found concentration of $\mathrm{Ca}, \mathrm{Cu}, \mathrm{K}, \mathrm{P}, \mathrm{Na}$ and $\mathrm{Zn}$ was similar to reference concentrations; while concentration of Co was lower than that and $\mathrm{Pb}$ was not detected (see columns 5 and 7 in Table 7). On the other hand, reference concentration of $\mathrm{Li}, \mathrm{Sr}, \mathrm{Ti}, \mathrm{V}$

Table 6

Evaluation of digestion procedures for SNi and L-1 sample analysis.

\begin{tabular}{|c|c|c|c|c|c|c|c|c|c|}
\hline \multirow[t]{2}{*}{ Sample } & \multirow[t]{2}{*}{ Element } & \multirow[t]{2}{*}{ Reference concentration } & \multicolumn{7}{|c|}{ Found concentration \pm confidence interval $(n=5, \alpha=0.05)$ in $\%, \mathrm{~m} / \mathrm{m}$} \\
\hline & & & D-1 & D-2 & D-3 & D-4 & D-5 & D-6 & $\mathrm{D}-7$ \\
\hline \multirow[t]{5}{*}{$\mathrm{SNi}$} & $\mathrm{Al}$ & $0.49 \pm 0.03$ & $0.48 \pm 0.03$ & $0.54 \pm 0.02$ & $0.51 \pm 0.02$ & - & - & - & - \\
\hline & $\mathrm{Cr}$ & $0.40 \pm 0.02$ & $0.38 \pm 0.03$ & $0.31 \pm 0.01$ & $0.40 \pm 0.01$ & - & - & - & - \\
\hline & $\mathrm{Fe}$ & $7.6 \pm 0.1$ & $7.5 \pm 0.3$ & $7.54 \pm 0.03$ & $7.6 \pm 0.1$ & - & - & - & - \\
\hline & $\mathrm{Mg}$ & $19.2 \pm 0.3$ & $19 \pm 1$ & $18.8 \pm 0.3$ & $20 . \overline{4} \pm 1.1$ & - & - & - & - \\
\hline & $\mathrm{Ni}$ & $1.92 \pm 0.03$ & $1.8 \pm 0.1$ & $1.76 \pm 0.02$ & $1.9 \pm 0.1$ & - & - & - & - \\
\hline \multirow[t]{5}{*}{ L-1 } & $\mathrm{Al}$ & $1.9 \pm 0.1$ & - & - & - & $1.82 \pm 0.04$ & $1.8 \pm 0.1$ & $1.7 \pm 0.1$ & $1.79 \pm 0.04$ \\
\hline & $\mathrm{Cr}$ & $1.97(1.89-1.99)^{\mathrm{b}}$ & - & - & - & $1.67 \pm 0.04$ & $1.64 \pm 0.03$ & $1.49 \pm 0.02$ & $1.68 \pm 0.03$ \\
\hline & $\mathrm{Fe}$ & $52.9 \pm 0.2$ & - & - & - & $51.6 \pm 0.6$ & $52 \pm \overline{1}$ & $52.0 \pm 0.4$ & $52.1 \pm 0.7$ \\
\hline & $\mathrm{Mg}$ & $0.41 \pm 0.03$ & - & - & - & $0.40 \pm 0.02$ & $0.39 \pm 0.02$ & $0.39 \pm 0.01$ & $0.41 \pm 0.01$ \\
\hline & $\mathrm{Ni}$ & $1.15 \pm 0.02$ & - & - & - & $1.05 \pm 0.01$ & $1.05 \pm 0.01$ & $1.06 \pm 0.01$ & $1.1 \pm 0.1^{\mathrm{a}}$ \\
\hline
\end{tabular}

a Confidence interval of $\mathrm{Ni}$ in L-1 digested by D-7 procedure was calculated for a confidence level $\alpha=0.01$.

b Median (Median interval).

Table 7

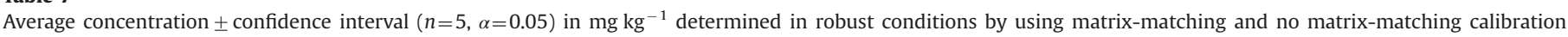
curves.

\begin{tabular}{|c|c|c|c|c|c|c|}
\hline \multirow[t]{3}{*}{ Element } & \multicolumn{3}{|l|}{ L-1 sample } & \multicolumn{3}{|l|}{ SNi sample } \\
\hline & \multirow[t]{2}{*}{ Reference concentration $^{\text {a }}$} & \multicolumn{2}{|c|}{ Found concent. \pm confidence interval ${ }^{b}$} & \multirow[t]{2}{*}{ Reference concentration ${ }^{a}$} & \multicolumn{2}{|c|}{ Found concent \pm confidence interval ${ }^{\mathrm{b}}$} \\
\hline & & Fe-matching & No matrix-matching & & Mg-matching & No matrix-matching \\
\hline $\mathrm{Ca}$ & $643 \pm 622$ & $567 \pm 83$ & $315 \pm 3$ & 1700 (1275-3329) & $1945 \pm 33$ & $1450 \pm 103$ \\
\hline Co & $740(710-750)$ & $698 \pm 15$ & $581 \pm 5$ & $150 \pm 8$ & $147 \pm 5$ & $104 \pm 7$ \\
\hline $\mathrm{Cu}$ & $42.6 \pm 3.6$ & $39.4 \pm 0.4$ & $40 \pm 1$ & $21^{\mathrm{c}}$ & $21 \pm 3$ & $18 \pm 3$ \\
\hline K & $332 \pm 184$ & $283 \pm 5$ & $287 \pm 3$ & $62 \pm 947$ & $52 \pm 8$ & $156 \pm 14$ \\
\hline $\mathrm{Na}$ & $445 \pm 269$ & $531 \pm 99$ & $606 \pm 1$ & $117 \pm 126$ & $117 \pm 2$ & $152 \pm 24$ \\
\hline $\mathrm{P}$ & $118 \pm 100$ & $97 \pm 6$ & $85 \pm 1$ & $90(11-1803)$ & $72 \pm 5$ & $65 \pm 6$ \\
\hline $\mathrm{Ti}$ & $707 \pm 61$ & $763 \pm 15$ & $727 \pm 8$ & No reported & $329 \pm 8$ & $408 \pm 12$ \\
\hline V & $183 \pm 43$ & $148 \pm 7$ & $122 \pm 1$ & No reported & $41 \pm 2$ & $37 \pm 5$ \\
\hline $\mathrm{Zn}$ & $317 \pm 48$ & $299 \pm 38$ & $268 \pm 3$ & $82 \pm 15$ & $88 \pm 10$ & $89 \pm 15$ \\
\hline $\mathrm{Li}$ & $4^{\mathrm{d}}-$ & $5.7 \pm 0.2$ & $5.5 \pm 0.2$ & No reported & $1.0 \pm 0.2$ & $1.1 \pm 0.2$ \\
\hline $\mathrm{Pb}$ & $37 \pm 3$ & $8.4 \pm 0.3$ & $7.7 \pm 0.2$ & No reported & $<0.7$ & $<0.7$ \\
\hline $\mathrm{Sr}$ & $16^{\mathrm{d}}$ & $5 \pm 1$ & $5 \pm 1$ & No reported & $2.5 \pm 0.1$ & $2.5 \pm 0.1$ \\
\hline $\mathrm{Zr}$ & $75^{\mathrm{d}}$ & $20.4 \pm 0.3$ & $18.6 \pm 0.3$ & No reported & $0.6 \pm 0.1$ & $0.8 \pm 0.1$ \\
\hline
\end{tabular}

${ }^{\text {a }}$ For $\mathrm{Ca}$ and $\mathrm{P}$ in $\mathrm{SNi}$; and for Co in $\mathrm{L}-1$, reference concentration is expressed as median (median interval).

${ }^{\mathrm{b}}$ For $\mathrm{Co}$ and $\mathrm{V}$ in $\mathrm{SNi}$; and Ca in L-1, confidence interval of found concentration was calculated with $\alpha=0.01$.

${ }^{c}$ Only median concentration is provided for $\mathrm{Cu}$.

${ }^{\mathrm{d}}$ Confidence interval of the average concentration was not provided 
and $\mathrm{Zr}$ are not given in the certificate. For these elements, except $\mathrm{Ti}$, found concentrations determined by using Mg-matching and no matrix-matching calibration curves were equals within the experimental error; which confirmed the absence of systematic error. Concentration of Ti, determined by using the Mg-matching calibration curves can be considered as the best result for this element in SNi sample. In L-1 sample analysis, found concentration was lower than reference one for $\mathrm{Co}, \mathrm{Pb}, \mathrm{Sr}, \mathrm{Zr}$ and $\mathrm{V}$; while it was higher for Li. For the remaining seven elements $\mathrm{Ca}, \mathrm{Cu}, \mathrm{K}, \mathrm{Na}$, $\mathrm{P}, \mathrm{Ti}$ and $\mathrm{Zn}$, the differences between found and reference concentration was not significantly (see columns 4 and 2 in Table 7).

Further, a second approach by using matrix-matching calibration curves was investigated. Thus, $1900 \mathrm{mg} \mathrm{L}^{-1}$ of $\mathrm{Mg}$ and $5000 \mathrm{mg} \mathrm{L}^{-1}$ of Fe were added, separately, to the both calibration dissolutions set for SNi and L-1 samples, respectively. With the use of Mg-matching calibration curve for SNi sample analysis, found concentration of Co became similar to the reference one; while the good results for $\mathrm{Ca}, \mathrm{Cu}, \mathrm{K}, \mathrm{P}, \mathrm{Na}$ and $\mathrm{Zn}$, previously obtained by using no matrix-matching curves, did not change (columns 6 and 5 in Table 7). In sample L-1, the use of the Fe-matching calibration curves reduced the systematic error of analysis for $\mathrm{Co}$ and $\mathrm{V}$; while found concentrations of $\mathrm{Li}, \mathrm{Pb}, \mathrm{Sr}$ and $\mathrm{Zr}$ were still different from the reference ones. For the rest of elements ( $\mathrm{Ca}, \mathrm{Cu}, \mathrm{K}, \mathrm{Na}, \mathrm{P}, \mathrm{Ti}$ and $\mathrm{Zn}$ ), found concentration determined with Fe-matching curves, kept similar to reference ones as it was obtained with the no matrix-matching calibration curve (columns 3 and 2 in Table 7).

In conclusion, the Fe-matching and Mg-matching curves should be used additionally to the selected robust conditions for a better reduction of the systematic error caused for the matrix effect.

\subsection{Evaluation of the method performance parameters}

In order to provide the first analytical information of the characteristics of the developed methodology, the most important performance parameters, accuracy, precision and limit of detection were evaluated. A full validation process will be carry out in the specific conditions of the geological service laboratory; in which the methodology will be implemented with routine analysis purposes. According to the previous results, robust operating parameters of the plasma were fixed and the Mg-matching and Fe-matching calibration curves for SNi and L-1 reference materials, respectively, were used.

As can be seen in Table 8, no significant differences were observed between found and references concentration for mostly elements in both samples. Statistical evaluation was made by applaying the $t$-Student test for a confidence level of $\alpha=0.05$ or $\alpha=0.01$ and six determinations. For some elements, statistical comparison was made by the overlapping of the provided median confidence intervals. In sample $\mathrm{L}-1$, some exceptions were observed: found concentration of $\mathrm{Cr}$ was significantly low because of the insufficient extraction of this element; which was observed previously in (see Table 6 in Section 3.4); found concentration of $\mathrm{Pb}$ was also lower than reference one. Some association between $\mathrm{Cr}$ and $\mathrm{Pb}$ in L-1 sample could explain this fact. Nevertheless, additional work has to be done in order to improve the $\mathrm{Cr}$ and $\mathrm{Pb}$ analysis. $\mathrm{Li}, \mathrm{Sr}$ and $\mathrm{Zr}$ in $\mathrm{L}-1$ were not evaluated because of the confidence interval of reference concentration was not provided. In sample SNi good agreement between found and reference concentration was established, except for $\mathrm{Li}, \mathrm{Sr}, \mathrm{Pb}, \mathrm{Ti}$ and $\mathrm{V}$; for which reference concentrations were not given.

Finally, the principal performance parameters of the developed methodology were calculated and given in Table 9. The accuracy error was estimated as the percentage difference between the mean concentration found by using the developed methodology and the reference concentration. In L-1 sample, accuracy error was around or lower than $10 \%$ for most of elements (Ca, Co, Cr, $\mathrm{Cu}, \mathrm{Ti}$, $\mathrm{Zn}, \mathrm{Al}, \mathrm{Cr}, \mathrm{Fe}, \mathrm{Mg}, \mathrm{Mn}$ and $\mathrm{Ni}$ ), except K (15\%), Na (19\%), P (19\%) and $\mathrm{V}(19 \%)$. It is important to note, that, in spite of the confidence interval of $\mathrm{Cr}$ found concentration in sample L-1 did not overlapped the confidence interval of the median reference concentration of $\mathrm{Cr}$ in reference material (see Table 8), the accuracy error was relatively low (9\%). Because of that reason, it is reasonable and practical to consider the determination of $\mathrm{Cr}$ in $\mathrm{L}-1$ as quantitative

Table 8

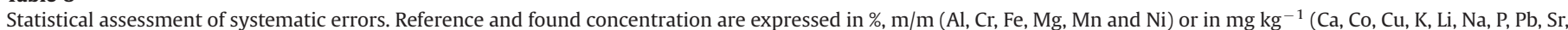
Ti, V, Zn and Zr).

\begin{tabular}{|c|c|c|c|c|c|c|c|c|}
\hline \multirow[t]{2}{*}{ Element } & \multicolumn{4}{|l|}{ L-1 reference material } & \multicolumn{4}{|l|}{ SNi reference material } \\
\hline & Reference concentration ${ }^{a}$ & Found concentration $^{\mathrm{b}}$ & $t_{\text {experimental }}$ & $t_{\text {table }}$ & Reference concentration ${ }^{a}$ & Found concentration $^{\mathrm{b}}$ & $t_{\text {experimental }}$ & $t_{\text {table }}$ \\
\hline $\mathrm{Ca}$ & $643 \pm 622$ & $567 \pm 83$ & 0.13 & 2.16 & 1700 (1275-3329) & $1945 \pm 33$ & c & c \\
\hline Co & $740(710-750)$ & $698 \pm 15$ & c & c & $150 \pm 8$ & $147 \pm 5$ & 0.4 & 2.08 \\
\hline $\mathrm{Cu}$ & $42.6 \pm 3.6$ & $39.4 \pm 0.4$ & 1.1 & 2.10 & 21 & $21 \pm 3$ & 0.3 & 2.57 \\
\hline K & $332 \pm 184$ & $283 \pm 5$ & 2.35 & 2.92 & $62 \pm 947$ & $52 \pm 8$ & 0.03 & 2.26 \\
\hline $\mathrm{Li}$ & $4^{\mathrm{d}}$ & $5.7 \pm 0.2$ & - & - & No reported & $1.0 \pm 0.2$ & - & - \\
\hline $\mathrm{Na}$ & $445 \pm 269$ & $531 \pm 99$ & 0.36 & 2.18 & $117 \pm 126$ & $117 \pm 2$ & 0.01 & 2.26 \\
\hline $\mathrm{Sr}$ & $16^{\mathrm{d}}-$ & $5 \pm 1$ & - & - & No reported & $2.5 \pm 0.1$ & - & - \\
\hline $\mathrm{P}$ & $118 \pm 100$ & $97 \pm 6$ & 0.9 & 2.13 & $90(11-1803)$ & $72 \pm 5$ & c & c \\
\hline $\mathrm{Pb}$ & $37 \pm 3$ & $8.4 \pm 0.3$ & 3.62 & 2.18 & No reported & $<0.7$ & - & - \\
\hline $\mathrm{Ti}$ & $707 \pm 61$ & $763 \pm 15$ & 1.0 & 2.06 & No reported & $329 \pm 8$ & - & - \\
\hline V & $183 \pm 43$ & $148 \pm 7$ & 1.9 & 2.18 & No reported & $41 \pm 2$ & - & - \\
\hline $\mathrm{Zn}$ & $317 \pm 48$ & $299 \pm 38$ & 0.6 & 2.08 & $82 \pm 15$ & $88 \pm 10$ & 2.0 & 2.18 \\
\hline $\mathrm{Zr}$ & $75^{\mathrm{d}}$ & $20.4 \pm 0.3$ & - & - & No reported & $0.6 \pm 0.1$ & - & - \\
\hline $\mathrm{Al}$ & $1.9 \pm 0.1$ & $1.8 \pm 0.1$ & 1.6 & 2.04 & $0.49 \pm 0.03$ & $0.43 \pm 0.03$ & 2.07 & 2.13 \\
\hline $\mathrm{Cr}$ & 1.97 (1.89-1.99) & $1.79 \pm 0.03$ & c & c & $0.40 \pm 0.03$ & $0.35 \pm 0.03$ & 2.58 & 2.92 \\
\hline $\mathrm{Fe}$ & $52.9 \pm 0.2$ & $53 \pm 1$ & 1.5 & 2.04 & $7.6 \pm 0.1$ & $7.5 \pm 0.2$ & 1.6 & 2.06 \\
\hline $\mathrm{Mg}$ & $0.41 \pm 0.02$ & $0.42 \pm 0.02$ & 0.0 & 2.04 & $19.2 \pm 0.3$ & $18.9 \pm 0.2$ & 1.5 & 2.86 \\
\hline $\mathrm{Mn}$ & $0.62 \pm 0.01$ & $0.63 \pm 0.02$ & 1.1 & 2.02 & $0.11 \pm 0.01$ & $0.10 \pm 0.01$ & 0.2 & 2.09 \\
\hline $\mathrm{Ni}$ & $1.15 \pm 0.02$ & $1.2 \pm 0.1$ & 0.9 & 2.04 & $1.92 \pm 0.03$ & $1.92 \pm 0.01$ & 0.13 & 2.02 \\
\hline
\end{tabular}

${ }^{a}$ Reference concentration is expressed as average concentration \pm confidence interval, with the exception of Co and Cr in L-1; and Ca and P in SNi, for which it is expressed as median concentration (median interval).

${ }^{\mathrm{b}}$ Confidence interval of found concentration was calculated with $n=6$ and $\alpha=0.05$, except $\mathrm{K}$ in $\mathrm{L}-1$; and $\mathrm{Al}$ and $\mathrm{Cr}$ in $\mathrm{SNi}$; for which was calculated with $n=6$ and $\alpha=0.01$.

c Statistical comparison was made by the overlapping (or not overlapping) of the median confidence intervals.

d Confidence interval for $\mathrm{Li}, \mathrm{Sr}$ and $\mathrm{Zr}$ in L-1 sample is not given. 
Table 9

Performance parameters of the developed analytical procedure.

\begin{tabular}{|c|c|c|c|c|c|c|}
\hline \multirow[t]{2}{*}{ Element } & \multicolumn{3}{|c|}{ L-1 reference material } & \multicolumn{3}{|c|}{ SNi reference material } \\
\hline & Accuracy (\%) & Precision (\%) & $\mathrm{LOD}^{\mathrm{a}}\left(\mathrm{mg} \mathrm{kg}^{-1}\right)$ & Accuracy (\%) & Precision (\%) & $\mathrm{LOD}^{\mathrm{a}}\left(\mathrm{mg} \mathrm{kg}^{-1}\right)$ \\
\hline $\mathrm{Ca}$ & 12 & 11 & 8 & 14 & 1.6 & 0.7 \\
\hline Co & 6 & 2.2 & 0.08 & 2.0 & 3.2 & 0.2 \\
\hline $\mathrm{Cu}$ & 8 & 0.5 & 0.1 & 1.9 & 14 & 0.2 \\
\hline $\mathrm{K}$ & 15 & 1.4 & 0.3 & 16 & 15 & 0.9 \\
\hline $\mathrm{Na}$ & 19 & 5.9 & 0.2 & 0.4 & 1.6 & 0.1 \\
\hline $\mathrm{P}$ & 19 & 6.2 & 0.6 & 20 & 7.1 & 0.1 \\
\hline $\mathrm{Ti}$ & 8 & 1.9 & 0.06 & $\mathrm{~b}$ & 2.4 & 0.2 \\
\hline V & 19 & 4.5 & 0.08 & b & 5.3 & 0.1 \\
\hline $\mathrm{Zn}$ & 6 & 11 & 0.09 & 7 & 10 & 0.2 \\
\hline $\mathrm{Al}$ & 5 & 5.3 & 1 & 12 & 3 & 1 \\
\hline $\mathrm{Cr}$ & 9 & 1.1 & 3 & 13 & 4.5 & 3 \\
\hline $\mathrm{Fe}$ & 0.2 & 1.8 & 3 & 1.3 & 2.6 & 3 \\
\hline $\mathrm{Mg}$ & 2.4 & 4.5 & 0.3 & 1.6 & 1.0 & 0.3 \\
\hline $\mathrm{Mn}$ & 1.6 & 3.0 & 0.4 & 5.5 & 9 & 0.4 \\
\hline $\mathrm{Ni}$ & 1.7 & 4.1 & 1 & 0.2 & 0.5 & 1 \\
\hline $\mathrm{Li}$ & -72 & 3 & 0.1 & b & 15 & 0.1 \\
\hline $\mathrm{Pb}$ & -77 & 3 & 1 & c & c & 0.7 \\
\hline $\mathrm{Sr}$ & -67 & 15 & 0.1 & b & 3 & 0.1 \\
\hline $\mathrm{Zr}$ & -73 & 1.5 & 0.7 & b & 13 & 0.3 \\
\hline
\end{tabular}

${ }^{a}$ LOD: limit of detection.

${ }^{\mathrm{b}}$ Accuracy was not assessed because reference concentrations were not available.

${ }^{\mathrm{c}} \mathrm{Pb}$ was not detected in SNi reference material.

one, until an additional work could improve this result. As expected, from the results discussed in Table 8, determination of $\mathrm{Li}, \mathrm{Pb}, \mathrm{Sr}$ and $\mathrm{Zr}$ in L-1 can be only qualitative because of the high ( $\sim 70 \%$ ) accuracy error obtained. In SNi sample, accuracy error was around or lower than $10 \%$ for most of elements ( $\mathrm{Co}, \mathrm{Cu}, \mathrm{Na}, \mathrm{Zn}, \mathrm{Al}$, $\mathrm{Cr}, \mathrm{Fe}, \mathrm{Mg}, \mathrm{Mn}$ and $\mathrm{Ni}$ ), except $\mathrm{Ca}(14 \%)$ and P (20\%). As noted before, $\mathrm{Li}, \mathrm{Sr}, \mathrm{Pb}$, Ti and $\mathrm{V}$ accuracy could not be evaluated because reference concentration is not given in SNi sample. Extra experiments are planned, in order to evaluate the accuracy of those elements by using another method, like for example the addedrecovered method or by comparison with the concentrations determined by another implemented methodology with different chemical and physical principles.

Precision, calculated as the relative standard deviation of the average $(n=6)$ concentration of the element, was very near or lower than $10 \%$ for mostly elements, except $\mathrm{Sr}$ (15\%) in L-1; and $\mathrm{K}$ (15\%) and $\mathrm{Li}(15 \%)$ in SNi sample.

At last, limit of detection was estimated as the concentration of the blank line intensity, measured from the matrix blank dissolution, plus three times the standard deviation. $5000 \mathrm{mg} \mathrm{L}^{-1}$ of Fe and $1900 \mathrm{mg} \mathrm{L}^{-1}$ of $\mathrm{Mg}$ in $4 \%(\mathrm{v} / \mathrm{v}) \mathrm{HNO}_{3}$ dissolutions were used as matrix blanks for L-1 and SNi samples, respectively. Limits of detection ranged from $0.06 \mathrm{mg} \mathrm{kg}^{-1}$ to $8 \mathrm{mg} \mathrm{kg}^{-1}$ in dependence of element and sample; which guaranteed a good detection of all elements, according to the expected concentrations.

\section{Conclusions}

Novel characteristics of the interfering effect due to $\mathrm{Al}+\mathrm{Cr}+\mathrm{Fe}$ $+\mathrm{Ni}$ and $\mathrm{Mg}+\mathrm{Fe}+\mathrm{Ni}$ complex matrices in dissolutions that simulated the major composition of laterite and serpentine mineral considered in this work, has been described. The predominant role of the principal component $\mathrm{Fe}$ on the matrix effect in laterite sample contrasted with the existence of an interaction effect between $\mathrm{Mg}$ and, probably, Fe in serpentine that modified the effect of the individual principal component $\mathrm{Mg}$ in the $\mathrm{Mg}+\mathrm{Fe}$ + Ni complex matrix of this sample.
An ICP OES methodology for the simultaneous quantitative determination of $\mathrm{Al}, \mathrm{Ca}, \mathrm{Co}, \mathrm{Cu}, \mathrm{Cr}, \mathrm{Fe}, \mathrm{K}, \mathrm{Mg}$, Mn, Na, Ni, P and $\mathrm{Zn}$ in Cuban laterite and serpentine minerals has been developed. Additionally, $\mathrm{V}$ and Ti can be quantitatively determined in laterite; and $\mathrm{Li}, \mathrm{Sr}$ and $\mathrm{Zr}$ can be detected in both mineral types; while $\mathrm{Pb}$ can be detected in laterite mineral.

\section{Acknowledgements}

This work has been performed in the frame of the International Cooperation Program of the Universidad Complutense de Madrid with the Universidad de la Habana; and also as part of the IMRE Project "Improvement of the reliability of the analysis of environmental samples and advanced materials", 2011 IMRE convocation.

\section{References}

[1] http://www.ecured.cu/index.php/Níquel_en_Moa. (Consulted: September 16, 2013).

[2] O.S. Barzaga, A.M. Hernández, A. Merayo, Ciencias Holguín 14 (2010) 1-9.

[3] O. Coto, F. Galizia, I. Hernández, J. Marrero, E. Donati, Hydrometallurgy 94 (2008) 18-22.

[4] J.A.C. Broekaert, Spectrochim. Acta, Part B 55 (2000) 739-751.

[5] I.B. Brenner, S. Vats, A.T. Zander, J. Anal. At. Spectrom. 14 (1999) 1231-1237.

[6] ISCL-319:2010 Determination of $\mathrm{Fe}, \mathrm{Ni}, \mathrm{Co}, \mathrm{SiO}_{2}, \mathrm{Al}_{2} \mathrm{O}_{3}, \mathrm{MnO}, \mathrm{Cr}_{2} \mathrm{O}_{3}$ and $\mathrm{MgO}$ in laterites and serpentines by ICP-AES. Fusion method. Quality Management System. UEB Laboratory, Geominera Oriente Enterprise, 2010.

[7] LRM-PT-01 Procedure for Determination of $\mathrm{Fe}, \mathrm{Ni}, \mathrm{Co}, \mathrm{SiO}_{2}, \mathrm{MgO}, \mathrm{Al}_{2} \mathrm{O}_{3}, \mathrm{Cr}_{2} \mathrm{O}_{3}$ and $\mathrm{MnO}$ by ICP- OES in raw mineral for nickel industry, Central Laboratory of Minerals (LACEMI) "José Isaac del Corral”, 2006.

[8] A New Approach to the High Concentration Chloride Leaching of Nickel Laterites, Bryn Harris, Carl White, Mal Jansen, Duncan Pursell, Presented at ALTA Ni/Co 11 Perth, WA, 2006.

[9] A New Process for Cobalt-Nickel Separation, D.L Jones, T.M. McCoy, K.E Mayhew, C.Y. Cheng, K.R. Barnard, W. Zhang, ALTA, 2010.

[10] H. Hong, Z. Li, P. Xiao, Clays Clay Miner. 57 (2009) 602-615.

[11] P.J. Lamothe, T.L. Fries, J.J. Consul, Anal. Chem. 58 (1986) 1881-1886.

[12] M. Totland, I. Jarvis, K. Jarvis, Chem. Geol. 95 (1992) 35-62.

[13] F. Le Cornec, C. Riandey, M.L. Richard, Minéralisation par micro-ondes de matériaux géologiques (roches et sols) et comparaison avec les méthodes classiques de mise en solution, in: D. Rambaud (Ed.), L'échantillonnage du prélèvement à l'analyse, E-Publishing Orstom, Paris, 1994.

[14] J.L. Kathryn, J.H. Steve, Analyst 123 (1998) 103R-133R.

[15] M. Chen, L.Q. Ma, Soil Sci. Soc. Am. J 65 (2001) 491-499. 
[16] H. Shun-feng, W. Xia, G. He-yan, J. Wei, Rock Miner. Anal. (2011) 465-468.

[17] W. Guo-xin, X. Yu-yu, W. Hui, L. Feng, W. Cheng, H. Qing, Rock Miner. (2011) $572-575$.

[18] Z. Li-wei, X. Yu-rong, Z. Wei, L. Wei-ping, Yunnan, Geology (2010) 346-350.

[19] N. Ponce, I. Altarriba, D. Carrillo, Serie Geológica 1 (1988) 75-82.

[20] F. Roja, C. Santana, Rev. Tecnol. 18 (1988) 8-15.

[21] J.M. Mermet, Anal. Chim. Acta 250 (1991) 85-94.

[22] J.M. Mermet, J. Anal. At. Spectrom 20 (2005) 11-16.

[23] A. Väisänen, A. Ilander, Anal. Chim. Acta 570 (2006) 93-100.

[24] M. Grotti, C. Lagomarsino, J.M. Mermet, J. Anal. At. Spectrom 21 (2006) 963-969.

[25] I.B Brenner, A.T. Zander, Spectrochim. Acta, Part B 55 (2000) 1195-1240.

[26] M. Iglésias, T. Vaculovic, J. Studynkova, E. Poussel, J.M. Mermet, Spectrochim. Acta, Part B 59 (2004) 1841-1851.
[27] I.B. Brenner, A. Zander, M. Cole, A. Wiseman, J. Anal. At. Spectrom 12 (1997) 897-906.

[28] F.V. Silva., C.L. Trevizan, C.S. Silva., A.R.A. Nogueira., J.A. Nóbrega, Spectrochim. Acta, Part B 57 (2002) 1905-1913.

[29] J. Davies, R.D. Snook, J. Anal. At. Spectrom. 1 (1986) 325-330.

[30] J.L. Todolí, L. Gras, V. Hernandis, J. Mora, J. Anal. At. Spectrom. 17 (2002) $142-169$.

[31] I.B. Brenner, M.Z.B. Maichin, G Knapp, J. Anal. At. Spectrom 13 (1998 1257-1264.

[32] M.T. Larrea, B. Zaldívar, J.C. Fariñas, L.G. Firgaira, M. Pomares, J. Anal. At Spectrom. 23 (2008) 145-151.

[33] M.E. Villanueva Tagle, M.T. Larrea Marín, O. Martin Gavilán, M.D. Durruthy Rodríguez, F. Calderón Piñar, M.S. Pomares Alfonso, Talanta 94 (2012) 50-57.

[34] L.C. Trevizan, J.A. Nóbrega, J. Braz. Chem. Soc 18 (2007) 678-690. 